\title{
Analisis Faktor-Faktor Yang Mempengaruhi Return Saham Pada Perusahaan Manufaktur Yang terdaftar di Bursa Efek Indonesia
}

\author{
Nia Tresnawaty, SE., M.Ak \\ niatresna@yahoo.com
}

Universitas Satya Negara Indonesia

\begin{abstract}
ABSTRAK
Pasar modal (capital market) merupakan pasar untuk berbagai instrumen keuangan jangka panjang yang bisa diperjualbelikan, baik surat utang (obligasi), ekuiti (saham), reksa dana, instrumen derivatif maupun instrumen lainnya. Pasar modal sebagai tempat bertemunya lender dan borrower menyediakan banyak informasi yang sangat dibutuhkan oleh investor maupun kreditor. Semakin pesatnya pasar modal, investor harus pintar dan teliti dalam melakukan investasi untuk dapat meraih keuntungan semaksimal mungkin dengan tingkat resiko yang sedikit. Oleh karena itu, laporan keuangan sangat berpengaruh untuk dijadikan sebuah acuan para investor dalam pengambilan keputusan pasar modal di Indonesia. Penelitian di bidang pasar modal pun telah banyak dilakukan diantaranya tentang faktor- faktor yang mempengaruhi Return Saham. Dari beberapa penelitian yang telah dilakukan terdapat perbedaan tentang variabelvariabel independen yang dipilih dan menghasilkan kesimpulan yang berbeda. Tujuan dari penelitian ini adalah untuk mendapatkan bukti empiris tentang faktorfaktor yang mempengaruhi Return Saham. Faktor-faktor yang diteliti adalah Laba Akuntansi (X1), Arus Kas Operasi (X2), Current Ratio (X3), Return Saham (X4). Penelitian ini menggunakan sampel berbagai perusahaan manufaktur sektor industri yang terdaftar di Bursa Efek Indonesia periode 2018-2020. Teknik pengambilan sampel dalam penelitian ini menggunakan teknik purposive sampling, dan diperoleh sampel sebanyak 168 sampel. Metode analisis dalam penelitian ini menggunakan analisis regresi linier berganda, dengan menggunakan software pengolah data statistik SPSS 25 for windows.

Hasil penelitian ini menunjukkan bahwa laba akuntansi, arus kas operasi, dan rasio lancar secara simultan berpengaruh signifikan terhadap return saham, sedangkan secara parsial laba akuntansi berpengaruh signifikan terhadap return saham, sedangkan arus kas operasi dan rasio lancar tidak berpengaruh signifikan terhadap return saham. pengembalian saham. . Hasil ini menunjukkan bahwa laba akuntansi memiliki dampak terhadap pasar saham, terutama terhadap pengembalian (return) dana yang diinvestasikan pada perusahaan manufaktur.
\end{abstract}

Kata kunci: laba akuntansi, arus kas operasi, rasio lancar, return saham 


\section{PENDAHULUAN}

Hal yang yang paling penting dalam menilai kemajuan perekonomian suatu negara salah satunya adalah dengan cara melihat seberapa jauh kondisi pasar modal suatu negara tersebut. Pengertian secara umum terkait pasar modal merupakan suatu bidang usaha perdagangan surat-surat berharga seperti saham, sekuritas efek dan obligasi.

Pasar modal memiliki fungsi penting yaitu sebagai sarana untuk memobilisasi dana yang bersumber dari masyarakat ke berbagai sektor yang melaksanakan investasi. Hal tersebut dikarenakan bahwa pasar modal merupakan media yang sangat efektif agar dapat menginvestasikan dan menyalurkan dana yang berdampak produktif dan menguntungkan bagi investor.

Aktivitas investasi saham merupakan salah satu cara investor untuk mendapatkan keuntungan atau memperluas bisnisnya. Investasi saham merupakan bentuk investasi yang diminati di pasar modal karena ada dua keuntungan yaitu berupa dividen dan capital gain. Biasanya seorang investor akan mengamati kondisi suatu perusahaan sebelum memutuskan untuk melakukan investasi, seperti dengan mempelajari laporan keuangan perusahaan, kinerja perusahaan, track record atau portofolio, keadaan perekonomian, risiko, ulasan tentang keuangan dan keadaan perekonomian yang dipublikasikan di media dan lain-lain.

Informasi yang terpercaya dan relevan mengenai dinamika stock price di pasar modal sangat diperlukan bagi investor untuk dapat memperoleh keuntungan yang maksimum atas investasi saham yang dilakukan Harga saham menunjukkan nilai perusahaan, semakin tinggi harga saham bisa diartikan bahwa semakin tinggi pula nilai perusahaan tersebut.

Kinerja perusahan merupakan alat untuk mengukur prestasi kerja suatu perusahaan atau badan usaha. Sehingga dapat diketahui perkembangan kondisi operasional perusahaan. Tujuan laporan keuangan berdasarkan Standard Akuntansi Keuangan (SAK) nomor 1 tahun 2018 adalah memberikan informasi mengenai posisi keuangan, kinerja keuangan,dan arus kas entitas yang bermanfaat bagi sebagian besar kalangan pengguna laporan dalam pembuatan keputusan ekonomi. Laporan keuangan juga menunjukkan hasil pertanggung jawaban manajemen atas sumber daya yang dipercayakan kepadanya, dalam rangka mencapai tujuan tersebut, laporan keuangan dipertimbangkan sebagai salah satu tanggung jawab pihak manajemen dengan pihak terkait dalam mengelola aset dalam periode tertentu.

Laba akuntansi didefinisikan sebagai kenaikan manfaat ekonomi selama periode akuntansi dalam bentuk penambahan aktiva atau penurunan kewajiban. Laba dapat menjadi pengukuran atas efisiensi serta sebagai pengukur keberhasilan dan sebagai pedoman pengambilan keputusan manajemen di masa mendatang. Penilaian atas laba juga merupakan tingkat pengembalian investasi (return), semakin besar laba yang diperoleh perusahaan, maka semakin baik di mata investor pada pasar modal. 
Arus kas dari aktivitas operasi diperoleh dari aktivitas penghasil utama pendapatan perusahaan. Arus kas dari aktivitas operasi merupakan indikator yang menentukan apakah aktivitas operasi perusahaan dapat menghasilkan arus kas yang cukup untuk melunasi pinjaman, memelihara kemampuan operasi perusahaan, membayar dividen, dan melakukan investasi baru tanpa mengandalkan sumber pendanaan dari luar. Komponen arus kas operasi ini yang dapat digunakan untuk menilai peluang investasi.

Current Ratio menunjukkan kemampuan perusahaan dalam memenuhi kewajiban jangka pendek dengan menggunakan aktiva lancar. Semakin tinggi current ratio di suatu perusahaan berarti semakin baik perusahaan dalam memenuhi kewajiban jangka pendek akan tetapi current ratio yang tinggi juga menunjukkan kelebihan aktiva lancar yang tidak digunakan secara maksimal. Current ratio yang terlalu tinggi menunjukkan kelebihan aktiva lancar yang menganggur sehingga tidak baik bagi profitabilitas perusahaan karena aktiva lancar menghasilkan return yang lebih rendah dibandingkan dengan aktiva tetap.

Berdasarkan latar belakang yang telah diuraikan diatas maka masalah yang akan dibahas adalah sebagai berikut:

1. Apakah laba akuntansi berpengaruh terhadap return saham pada perusahaan manufaktur yang terdaftar di BEI periode2018-2020?

2. Apakah arus kas operasi berpengaruh terhadap return saham pada perusahaan manufaktur yang terdaftar di BEI periode 2018-2020?

3. Apakah cerrent ratio berpengaruh terhadap return saham pada perusahaan manufaktur yang terdaftar di BEI periode 2018-2020?

\section{LANDASAN TEORI}

\section{Pasar Modal}

Definidi Pasar Modal Menurut Undang-Undang No. 8 Tahun 1995, adalah kegiatan yang bersangkutan dengan penawaran umum dan perdagangan efek, perusahaan publik yang berkaitan dengan efek yang telah diterbitkannya, serta lembaga dan profesi yang berkaitan dengan efek. Efek dapat dikategorikan sebagai hutang dan ekuitas seperti obligasi dan saham. Efek tersebut dapat terdiri dari surat pengakuan hutan, surat berharga komersial, saham obligasi, unit penyertaan investasi kolektif (seperti misalnya reksadana, kontrak berjangka atas efek, dan setiap derivatif dari efek).

\section{Laba Akuntansi}

Menurut Hanafi (2010:32) Laba merupakan ukuran keseluruhan prestasi perusahaan yang diukur dengan menghitung selisih antara pendapatan dan biaya. Laba akuntansi didefinisikan sebagai perbedaan antara pendapatan yang direalisasikan dari transaksi yang terjadi selama satu periode dengan biaya yang berkaitan dengan pendapatan tersebut. Informasi laba sering dilaporkan dalam penerbitan laporan keuangan dan digunakan secara luas oleh pemegang saham dan penanam modal potensial dalam mengevaluasi kemampuan perusahaan. Laba 
dipakai untuk mengukur efesiensi suatu perusahaan dalam penggunaan sumber daya ekonomi perusahaan.

\section{Arus Kas Operasi}

Menurut Pernyataan Standar Akuntansi Keuangan (PSAK) Nomor 2 Tahun 2018 mendefinisikan arus kas dari aktivitas operasi diperoleh dari aktivitas penghasil utama pendapatan perusahaan. Oleh karena itu, arus kas tersebut pada umumnya berasal dari transaksi dan peristiwa lain yang mempengaruhi penetapan laba atau rugi. Jumlah arus kas yang berasal dari aktivitas operasi merupakan indikator yang menentukan apakah operasi perusahaan dapat menghasilkan arus kas yang cukup untuk melunasi pinjaman, memelihara kemampuan operasi perusahaan, membayar deviden dan melakukan investasi baru tanpa mengandalkan sumber pendanaan dari luar (Ikatan Akuntansi Indonesia, 2018).

\section{Current Ratio}

Menurut Kasmir (2018:134) Current ratio merupakan rasio untuk mengukur kemampuan perusahaan dalam membayar kewajiban jangka pendek atau utang yang segera jatuh tempo pada saat dirtagih secara keseluruhan. Dengan kata lain, seberapa banyak aktiva lancar yang tersedia untuk menutupi kewajiban jangka pendek yang segera jatuh Tempo. Perhitungan rasio lancar dilakukan dengan cara membandingkan antara total aktiva lancar dengan total utang lancar

\section{METODOLOGI PENELITIAN}

Penelitian ini adalah penelitian kuantitatif dengan menggunakan metode analisis data deskriptif, yaitu data yang diperoleh nantinya akan diolah sesuai dengan teori-teori yang telah dipelajari dan kemudian akan diberi gambaran mengenai hasil dari data yang telah diolah. Penelitian ini akan dilakukan dengan menggunakan tiga variabel utama yaitu laba akuntansi, arus kas operasi, current ratio. Analisis hasil penelitian akan dilakukan dengan menggunakan metode analisis regresi linier berganda.

\section{Populasi dan Sampel}

Populasi yang digunakan dalam penelitian ini adalah seluruh perusahaan manufaktur yang terdaftar di Bursa Efek Indonesia pada tahun 2018 - 2020. Metode pengambilan sampel yang digunakan adalah purposive sampling. Adapun kriteria sampel yang digunakan sebagai berikut :

1. Perusahaan manufaktur yang sudah go public dan telah terdaftar di Bursa efek Indonesia (BEI) secara berturut-turut untuk periode 2018-2020.

2. Perusahaan yang menggunakan mata uang rupiah.

3. Perusahan yang mengalami laba terus-menerus untuk periode 2018-2020. 


\section{Metode Analisis Data}

\section{Analisis Statistik Deskriptif}

Metode statistik deskriptif merupakan pencatatan data yang disertai dengan kalimat, kata maupun gambar untuk memberikan gambaran mengenai variabel yang diteliti, namun tidak digunakan untuk membuat kesimpulan. Uji statistik deskriptif mencakupnilai rata-rata, nilai minimum, nilai maksimum, dan nilai standar deviasi dari data penelitian.

\section{Uji Asumsi Klasik}

\section{Uji Normalitas}

Menurut Imam Ghozali (2018: 161), Uji normalitas bertujuan untuk menguji apakah dalam model regresi, variabel dependen dan variabel independen mempunyai distribusi normal atau tidak. Model regresi yang baik adalah yang memiliki distribusi data normal/mendekati normal..

2. Uji Multikolinearitas

Menurut Imam Ghozali (2018:107), uji multikolinearitas bertujuan untuk menguji apakah model regresi ditemukan adanya kolerasi antar variable bebas (independen). Model regresi yang baik seharusnya tidak terjadi kolerasi diantara variable independen.

\section{Uji Heterokedastisitas}

Menurut Imam Ghozali (2018:137), uji heteroskedastisitas bertujuan menguji apakah model regresi terjadi ketidaksamaan variance dari residual satu pengamatan ke pengamatan lain. Jika variance dari residual satu pengamatan ke pengamatan lain tetap, maka disebut Homokedastisitas dan jika berbeda disebut Heteroskedastisitas.

\section{Uji Autokorelasi}

Menurut Imam Ghozali (2018:111), Uji autokorelasi bertujuan untuk menguji apakah dalam model regresi linier ada korelasi antara kesalahan pengganggu pada periode t-1 (sebelumnya). Jika terjadi korelasi, maka dinamakan ada problem autokorelasi. Autokorelasi muncul karena observasi yang berurutan sepanjang waktu berkaitan satu sama yang lainnya. Model regresi yang baik adalah regresi yang bebas dari autokorelasi.

\section{Analisis Regresi Linier Berganda}

Metode analisis data pada penelitian ini menggunakan metode regresi berganda. Analisis regresi berganda digunakan untuk menguji hubungan beberapa variabel independen terhadap variabel dependen. Variabel yang digunakan pada penelitian ini terdiri dari satu variabel dependen dan dua variabel independen. Persamaan regresi pada penelitian ini adalah sebagai berikut :

$$
\mathrm{Y}=\alpha+\mathrm{b} 1 \mathrm{X} 1+\mathrm{b} 2 \mathrm{X} 2+\mathrm{b} 3 \mathrm{X} 3+\mathrm{e}
$$




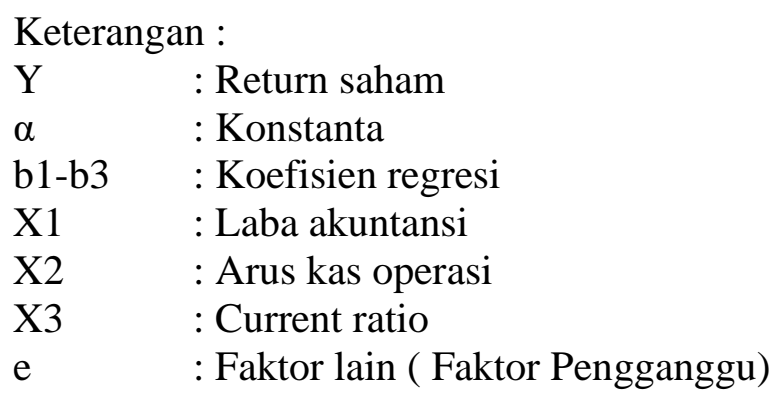

\section{Uji Statistik F}

Uji simultan dengan $f$ test ini bertujuan untuk mengetahui pengaruh bersama-sama variabel independen terhadap variabel dependen. Uji $f$ diperuntukkan untuk melakukan uji hipotesis koefisien (slope) regresi secara bersamaan.

\section{Uji Statistik t}

Uji t (uji parsial) digunakan untuk mengetahui pengaruh masing - masing variabel independen terhadap variabel dependen.

Menentukan tingkat signifikan $(\alpha)$ yaitu sebesar 5\% dapat dilakukan dengan berdasarkan nilai probabilitas, dengan cara pegambilan keputusan adalah :

1. Jika nilai probabilitas $>0,05$ maka Ho diterima

2. Jika nilai probabilitas $<0,05$ maka Ho ditolak

\section{Koefisien Determinasi ( R2 )}

Koefisien determinasi (R2) digunakan untuk mengetahui sejauh mana kontribusi variabel independen terhadap variabel dependen dengan adanya regresi linier berganda. Nilai R2 adalah 0 dan $1(0<\mathrm{R} 2<1)$, dimana suatu regresi yang baik akan menghasilkan nilai R2 yang tinggi. Hal ini berarti bahwa keseluruhan variabel bebas secara bersama-sama mampu menerangkan variabel terikatnya. Sedangkan nilai R2 kecil berarti kemampuan variabel-variabel dependen sangat terbatas.

\section{ANALISIS DAN PEMBAHASAN}

\section{Statistik Deskriptif}

Karena data tidak berdistribusi dengan normal maka dilakukan penormalan data dengan mengeluarkan data yang bernilai ekstrem ( outlier ) dapat diketahui menggunakan casewise diagnosis. Melalui proses outlier, terdapat 42 data yang ekstrem yang dikeluarkan sehingga data penelitian yang berdistribusi normal berjumlah 168 data. 
Descriptive Statistics

\begin{tabular}{lc|c|c|c|r} 
& $\mathrm{N}$ & $\begin{array}{c}\text { Minimu } \\
\mathrm{m}\end{array}$ & $\begin{array}{c}\text { Maximu } \\
\mathrm{m}\end{array}$ & Mean & Std. Deviation \\
\hline $\begin{array}{l}\text { LABA } \\
\text { AKUNTANSI }\end{array}$ & 168 &,- 9156 & 2,1744 &, 047782 &, 4592441 \\
\hline $\begin{array}{l}\text { ARUS KAS } \\
\text { OPERASI }\end{array}$ & 168 & $-9,7499$ & 9,4220 &, 107833 & 1,8764784 \\
\hline CURRENT RATIO & 168 &, 6337 & 8,0505 & 2,402481 & 1,5412784 \\
\hline RETURN SAHAM & 168 &,- 6462 &, 6538 &, 010737 &, 2385674 \\
\hline Valid N (listwise) & 168 & & & & \\
\hline Sumber : Hasil Output & & & & &
\end{tabular}

Sumber : Hasil Output SPSS, 2021

\section{Laba Akuntansi}

Berdasarkan tabel tersebut di atas bahwa perusahaan manufaktur periode tahun 2018-2020 memiliki kenaikan laba rata-rata 0,47782 atau 47,7\% dalam 3 tahun. Sedangkan nilai minimum yang diperoleh sebesar $-0,9156$ dan nilai maksimum sebesar 2,1744. Nilai standar deviation sebesar 0,4592441 lebih besar dari nilai mean 0,047782, hal ini menunjukkan bahwa data sampel menyebar (bervariasi) dan memiliki kecenderungan setiap data berbeda satu sama lain.

\section{Arus Kas Operasi}

Berdasarkan tabel tersebut di atas bahwa perusahaan manufaktur periode tahun 2018-2020 memiliki kenaikan arus kas operasi rata-rata sebesar 0,107833 atau 10,7\% dalam 3 tahun. Sedangkan nilai minimum yang diperoleh sebesar -9,7499 dan nilai maksimum sebesar 9,4220. Nilai standar deviation sebesar 1,8764784 lebih besar dari nilai mean 0,107833 , hal ini menunjukkan bahwa data sampel menyebar (bervariasi) dan memiliki kecenderungan setiap data berbeda satu sama lain.

\section{Current Ratio}

Berdasarkan tabel tersebut di atas bahwa perusahaan manufaktur periode tahun 2018-2020 memiliki kenaikan current ratio rata-rata sebesar 2,402481 atau 240,2\% dalam 3 tahun. Sedangkan nilai minimum yang diperoleh sebesar 0,6337 dan nilai maksimum sebesar 8,0505. Nilai standar deviation sebesar 1,5412784 lebih kecil dibandingkan dengan nilai mean (rata-rata) yaitu sebesar 2,402481 berarti simpangan Current Ratio dapat dikatakan relatif baik.

\section{Return Saham}

Berdasarkan tabel tersebut di atas bahwa perusahaan manufaktur periode tahun 2018-2020 memiliki kenaikan return saham rata-rata sebesar 0,010737 selama 3 tahun. Sedangkan nilai minimum yang diperoleh sebesar $-0,6462$ dan nilai maksimum sebesar 0,6538. Nilai standar deviation sebesar ,2385674 lebih besar dari nilai mean 0,010737, hal ini menunjukkan bahwa data sampel menyebar (bervariasi) dan memiliki kecenderungan setiap data berbeda satu sama lain. 
Uji Asumsi Klasik

1. Uji Normalitas

One-Sample Kolmogorov-Smirnov Test

\begin{tabular}{llr}
\hline N & & 168 \\
\hline Normal Parameters & &, 0000000 \\
& Mean &, 22862624 \\
\cline { 2 - 3 } & Std. Deviation &, 054 \\
\hline Most Extreme & Absolute &, 038 \\
\cline { 2 - 3 } & Positive &,- 054 \\
\cline { 2 - 3 } & Negative &, 054 \\
\hline Test Statistic & &, $200^{\mathrm{c}, \mathrm{d}}$ \\
\hline Asymp. Sig. (2-tailed) & & \\
\hline Sumber $:$ Hasil Output & & SPSS, 2021 \\
\hline
\end{tabular}

Sumber : Hasil Output SPSS, 2021

Hasil uji normalitas menunjukkan bahwa data penelitian telah berdistribusi normal yang dibuktikan dengan nilai Asymp. Sig sebesar 0,200 bernilai lebih besar dari tingkat signifikasi penelitian sebesat 0,05 . Oleh karena data penelitian telah berdistribusi normal, maka dapat digukan untuk pengujian dengan medel regresi berganda.

2. Uji Multikolinearitas

\section{Coefficients $^{\mathrm{a}}$}

\begin{tabular}{|c|c|c|c|}
\hline \multirow{2}{*}{\multicolumn{2}{|c|}{ Model }} & \multicolumn{2}{|c|}{ Collinearity Statistics } \\
\hline & & Tolerance & VIF \\
\hline \multirow[t]{3}{*}{1} & $\begin{array}{l}\text { LABA } \\
\text { AKUNTANSI }\end{array}$ & ,983 & 1,017 \\
\hline & $\begin{array}{l}\text { ARUS KAS } \\
\text { OPERASI }\end{array}$ & ,991 & 1,009 \\
\hline & CURRENT RATIO & ,985 & 1,015 \\
\hline
\end{tabular}

Sumber : Hasil Output SPSS, 2021

hasil pengujian multikolinearitas menunjukkan bahwa variabel bebas Laba Kuntansi memiliki nilai tolerance $=0,983>0,1$ dan nilai VIF $=1,017<$ 10 , sedangkan variabel bebas Arus Kas Operasi memiliki nilai tolerance $=$ $0,991>0,1$ dan nilai VIF $=1,009<10$, dan varibel bebas Current Ratio memiliki nilai tolerance $=0,985>0,1$ dan nilai VIF $=1,015<10$.Dengan demikian model regresi tersebut tidak memiliki masalah multikolinearitas. 
3. Uji Heteroskedastisitas

\section{Coefficients $^{\mathrm{a}}$}

\begin{tabular}{lr|r|r|r|r} 
& \multicolumn{2}{c|}{$\begin{array}{c}\text { Unstandardized } \\
\text { Coefficients }\end{array}$} & $\begin{array}{c}\text { Standardized } \\
\text { Coefficients }\end{array}$ & & \\
Model & B & Std. Error & \multicolumn{1}{c|}{ Beta } & \multicolumn{1}{c|}{ t } & \multicolumn{1}{c|}{ Sig. } \\
\hline (Constant) &, 173 &, 021 & & 8,146 &, 000 \\
\hline $\begin{array}{l}\text { LABA } \\
\text { AKUNTANSI }\end{array}$ &, 015 &, 025 &, 048 &, 609 &, 544 \\
\hline $\begin{array}{l}\text { ARUS KAS } \\
\text { OPERASI }\end{array}$ &,- 002 &, 006 &,- 027 &,- 349 &, 727 \\
\hline CURRENT RATIO &, 001 &, 007 &, 013 &, 162 &, 871 \\
\hline
\end{tabular}

a. Dependent Variable: ABRESID

Sumber : Hasil Output SPSS, 2021

Berdasarkan output spss diperoleh nilai signifikan variabel laba akuntansi sebesar 0,544 lebih besar dari 0,05, artinya tidak terdapat heteroskedastisitas pada variabel laba akuntansi. Begitu juga dengan variabel arus kas operasi dengan nilai signifikan 0,727 lebih besar dari 0,05 yang artinya tidak terdapat heteroskedastisitas, dan pada variabel current ratio diperoleh nilai signifikan sebesar 0,871 lebih besar dari 0,05 Dengan demikian dapat disimpulkan bahwa tidak terjadi masalah heteroskedastisitas pada model regresi karena nilai signifikan (sig) ketiga variabel $>0,05$.

\section{Uji Autokorelasi}

\begin{tabular}{cc|c|c|c|c} 
& \multicolumn{9}{c}{ Model Summary $^{\mathbf{b}}$} \\
Model & $\mathrm{R}$ & $\mathrm{R}$ & $\begin{array}{c}\text { Adjusted } \\
\text { Square }\end{array}$ & $\begin{array}{c}\text { Std. Error } \\
\text { of the } \\
\text { Estimate }\end{array}$ & $\begin{array}{c}\text { Durbin } \\
\text { Watso } \\
\mathrm{n}\end{array}$ \\
\hline 1 &, $286^{\mathrm{a}}$ &, 082 &, 065 &, 2307079 & 2,156 \\
\hline
\end{tabular}

a. Predictors: (Constant), CURRENT RATIO, ARUS KAS OPERASI, LABA AKUNTANSI

b. Dependent Variable: RETURN SAHAM

Sumber : Hasil Output SPSS, 2021

Diketahui bahwa nilai durbin watson adalah 2,156. Jika nilai durbin watson tersebut diantara du dan 4-du ( $d u<d<4-d u)$ maka tidak terjadi masalah autokorelasi. 
Hasil Uji Autokorelasi dengan Durbin Watson (DW Test)

\begin{tabular}{|c|l|c|c|c|}
\hline $\begin{array}{l}\text { Autokorelasi } \\
\text { positf }\end{array}$ & $\begin{array}{l}\text { Daerah ragu- } \\
\text { ragu }\end{array}$ & $\begin{array}{l}\text { Tidak ada } \\
\text { autokorelasi }\end{array}$ & $\begin{array}{l}\text { Daerah ragu- } \\
\text { ragu }\end{array}$ & $\begin{array}{l}\text { Autkorelasi } \\
\text { negative }\end{array}$ \\
\hline \multicolumn{1}{c|}{$\begin{array}{c}\mathrm{dl} \\
1,7115\end{array}$} & $\mathrm{du}$ & $\begin{array}{c}4-\mathrm{du} \\
2,7841\end{array}$ & $\begin{array}{l}4-\mathrm{dl} \\
2,885\end{array}$ \\
& \multicolumn{4}{c}{ Nilai $\mathrm{DW}=2,156$}
\end{tabular}

Sumber : Data diolah tahun 2021

Berdasarkan hasil uji autokorelasi dengan durbin watson diatas menunjukkan bahwa nilai durbin watson 2,156 berada diantara nilai du dan 4-du, maka dapat disimpulkan bahwa tidak terjadi masalah autokorelasi.

\section{Analisis Regresi Linier Berganda}

\begin{tabular}{|c|c|c|c|c|c|c|}
\hline \multicolumn{7}{|c|}{ Coefficients $^{\mathrm{a}}$} \\
\hline \multirow{2}{*}{\multicolumn{2}{|c|}{ Model }} & \multicolumn{2}{|c|}{$\begin{array}{l}\text { Unstandardized } \\
\text { Coefficients }\end{array}$} & \multirow{2}{*}{$\begin{array}{l}\text { Standardize } \\
\mathrm{d} \\
\text { Coefficients } \\
\text { Beta }\end{array}$} & \multirow[b]{2}{*}{$\mathrm{t}$} & \multirow[b]{2}{*}{ Sig. } \\
\hline & & $\mathrm{B}$ & Std. Error & & & \\
\hline \multirow[t]{4}{*}{1} & (Constant) &,- 001 & ,033 & &,- 034 & ,973 \\
\hline & $\begin{array}{l}\text { LABA } \\
\text { AKUNTANSI }\end{array}$ & , 130 & 039 & 250 & 3,317 & 001 \\
\hline & $\begin{array}{l}\text { ARUS KAS } \\
\text { OPERASI }\end{array}$ & ,016 &, 010 & ,122 & 1,629 & 105 \\
\hline & CURRENT RATIO & ,002 & ,012 & ,011 & 142 & 888 \\
\hline
\end{tabular}

\section{a. Dependent Variable: RETURN SAHAM}

Sumber : Hasil Output SPSS, 2021

Berdasarkan hasil uji analisis pada tabel tersebut di atas dapat diperoleh persamaan regresi linier berganda sebagai berikut :

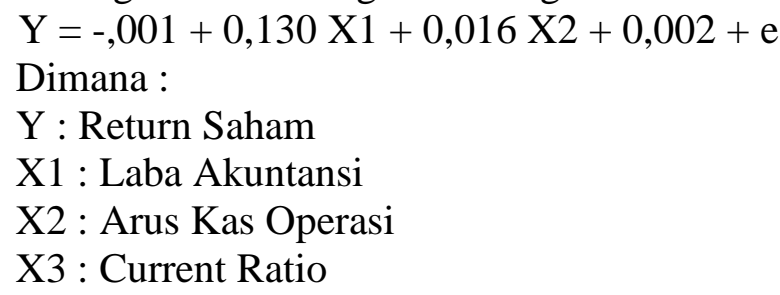


Hasil persamaan regresi ini secara keseluruhan menunjukkan hasil intrepretasi sebagai berikut :

1) Nilai konstanta untuk persamaan regresi sebesar -,001 menyatakan bahwa jika tidak terdapat laba akuntansi (X1), arus kas operasi (X2), dan current ratio (X3) atau sama dengan nol maka return saham (Y) nilainya adalah -,001.

2) Koefisien regresi untuk laba akuntansi sebesar 0,130 dan bertanda positif, hal ini berarti bahwa setiap perubahan satu satuan pada Laba Akuntansi dengan asumsi variabel lainnya tetap, maka return sahamnya aka mengalami perubahan sebesar 0,130 dengan arah yang sama.

3) Koefisien regresi untuk arus kas operasi sebesar 0,016 dan bertanda positif, hal ini berarti bahwa setiap perubahan satu satuan pada Arus Kas Operasi dengan asumsi variabel lainnya tetap, maka return saham akan mengalami perubahan sebesar 0,016 dengan arah yang sama.

4) Koefisien regresi untuk Current Ratio (CR) sebesar 0.002 dan bertanda positif, hal ini berarti bahwa setiap perubahan satu satuan pada Current Ratio dengan asumsi variabel lainnya tetap, maka return saham akan mengalami perubahan sebesar 0,002 dengan arah yang sama.

Berdasarkan persamaan regresi diperoleh hasil laba akuntansi mempunyai pengaruh yang dominan, hal ini mengindikasikan bahwa laba akuntansi merupakan sumber informasi penentu dalam proses pengambilan keputusan terutama dalam bidang investasi. Dari sudut pandang investor, laba akuntansi yang meningkat dapat memberikan sinyal positif mengenai prospek dan kinerja perusahaan di masa depan. Peningkatan laba akuntansi dapat mendorong investor untuk lebih tertarik dalam membeli saham perusahaan. Ketertarikan investor untuk membeli saham perusahaan akan dapat meningkatkan harga saham perusahaan dan berujung pada meningkatnya return saham perusahaan.

\section{Uji F ( Uji Simultan )}

\section{Hasil Uji F}

\begin{tabular}{|c|c|c|c|c|c|c|}
\hline \multicolumn{7}{|c|}{ ANOVA $^{a}$} \\
\hline \multicolumn{2}{|c|}{ Model } & $\begin{array}{l}\text { Sum of } \\
\text { Squares }\end{array}$ & $\mathrm{df}$ & $\begin{array}{l}\text { Mean } \\
\text { Square }\end{array}$ & F & Sig. \\
\hline \multirow[t]{3}{*}{$\overline{1}$} & Regression & ,776 & 3 & ,259 & 4,857 &, $003^{\mathrm{b}}$ \\
\hline & Residual & 8,729 & 164 & ,053 & & \\
\hline & Total & 9,505 & 167 & & & \\
\hline
\end{tabular}

a. Dependent Variable: RETURN SAHAM

b. Predictors: (Constant), CURRENT RATIO, ARUS KAS OPERASI, LABA AKUNTANSI

Sumber : Hasil Output SPSS, 2021 
Berdasarkan hasil tersebut maka dapat disimpulkan bahwa ketiga variabel independen yakni laba akuntansi, arus kas operasi, dan current ratio secara simultan berpengaruh signifikan terhadap variabel dependen yaitu return saham. F hitung yang didapat dari output sebesar 4,857 ( $\mathrm{df} 1=\mathrm{k}$ dan df $2=\mathrm{n}-\mathrm{k} ; \mathrm{df} 1=3$ dan df $2=$ 165) dimana $\mathrm{k}$ adalah variabel independen sedangkan $\mathrm{n}$ adalah jumlah sampel penelitian. Sehingga diperoleh F tabel sebesar 2,66 . Karena F hitung 4,857 > 2,66, dan Nilai signifikansi yang diperoleh sebesar $0,003<0,05$.

\section{Uji t ( Uji Parsial )}

\begin{tabular}{|c|c|c|c|c|c|c|}
\hline \multicolumn{7}{|c|}{$\begin{array}{c}\text { Hasil Uji t } \\
\text { Coefficients }^{\mathrm{a}}\end{array}$} \\
\hline \multirow{2}{*}{\multicolumn{2}{|c|}{ Model }} & \multicolumn{2}{|c|}{$\begin{array}{l}\text { Unstandardized } \\
\text { Coefficients }\end{array}$} & \multirow{2}{*}{$\begin{array}{l}\text { Standardized } \\
\text { Coefficients } \\
\text { Beta }\end{array}$} & \multirow[b]{2}{*}{$\mathrm{t}$} & \multirow[b]{2}{*}{ Sig. } \\
\hline & & B & $\begin{array}{l}\text { Std. } \\
\text { Error }\end{array}$ & & & \\
\hline \multirow[t]{4}{*}{1} & (Constant) &,- 001 & ,033 & &,- 034 & ,973 \\
\hline & $\begin{array}{l}\text { LABA } \\
\text { AKUNTANSI }\end{array}$ &, 130 & ,039 &, 250 & 3,317 & ,001 \\
\hline & $\begin{array}{l}\text { ARUS KAS } \\
\text { OPERASI }\end{array}$ & ,016 & ,010 &, 122 & 1,629 & ,105 \\
\hline & $\begin{array}{l}\text { CURRENT } \\
\text { RATIO }\end{array}$ & ,002 & ,012 & ,011 &, 142 & ,888 \\
\hline
\end{tabular}

a. Dependent Variable: RETURN SAHAM

Sumber : Hasil Output SPSS, 2021

1) Variabel laba akuntansi (X1) diperoleh nilai signifikansi 0,001 dan t hitung yang diperoleh adalah 3,317, Maka nilai signifikansi $0,001<0,05$ dan nilai t hitung 3,317> 1,97453. Maka dapat disimpulkan bahwa Ha diterima dan Ho ditolak. Dengan demikian hipotesis Ha1 diterima yaitu variabel laba akuntansi berpengaruh signifikan terhadap return saham pada perusahaan manufaktur yang terdaftar di Bursa Efek Indonesia.

2) Variabel arus kas operasi (X2) diperoleh nilai signifikansi 0,105 dan thitung yang diperoleh adalah 1,629. Maka nilai signifikansi $0,105>0,05$ dan nilai $t$ hitung 1,629 < 1,97453. Maka dapat disimpulkan bahwa Ho diterima dan Ha ditolak. Dengan demikian hipotesis Ho2 diterima yaitu variabel arus kas operasi tidak berpengaruh secara signifikan terhadap return saham pada perusahaan manufaktur yang terdaftar di Bursa Efek Indonesia.

3) Variabel current ratio (X3) diperoleh nilai signifikansi 0,888 dan thitung yang diperoleh adalah 0,142. Maka nilai signifikansi 0,888 > 0,05 dan nilai t hitung $0,142<1,97453$. Maka dapat disimpulkan bahwa Ho diterima dan Ha ditolak. 
Dengan demikian hipotesis Ho3 diterima yaitu variabel current ratio tidak berpengaruh secara signifikan terhadap return saham pada perusahaan manufaktur yang terdaftar di Bursa Efek Indonesia.

\section{Uji Koefisien Determinasi}

\section{Hasil Uji Koefisien Determinasi}

\begin{tabular}{|c|c|c|c|c|}
\hline \multicolumn{5}{|c|}{ Model Summary } \\
\hline Model & $\mathrm{R}$ & R Square & Adjusted R Square & Std. Error of the Estimate \\
\hline$\overline{1}$ & $286^{\mathrm{a}}$ & ,082 & $\overline{0}, 065$ & 2,2307079 \\
\hline
\end{tabular}

a. Predictors: (Constant), CURRENT RATIO, ARUS KAS OPERASI, LABA AKUNTANSI

b. Dependent Variable: RETURN SAHAM

Sumber : Hasil Output SPSS, 2021

Berdasarkan hasil uji koefisien determinasi model summary menunjukkan bahwa nilai koefisien determinasi Adjusted R square sebesar 0,065. Hal ini berarti bahwa seluruh variabel independen yaitu laporan akuntansi, arus kas operasi, dan current ratio yang mempengaruhi variabel dependent return saham adalah sebesar 6,5\% dan sisanya sebesar 93,5\% dipengaruhi oleh variabel lain yang tidak diteliti dalam penelitian ini.

\section{Pembahasan}

\section{Pengaruh Laba Akuntansi Terhadap Return Saham}

Besarnya laba akuntansi diukur melalui selisih antara jumlah pendapatan perusahaan dikurangi dengan biaya operasional perusahaan. Berdasarkan hasil pengujian hipotesis yang dilakukan dari analisis tabel 4.12 Hasil Uji $t$, besarnya laba akuntansi diperoleh nilai t hitung 3,317 > 1,97453 dan nilai signifikan sebesar $0,001<0,05$ sehingga Ho ditolak dan Ha diterima, artinya bahwa variabel laba akuntansi berpengaruh signifikan terhadap return saham pada perusahaan manufaktur yang terdaftar di Bursa Efek Indonesia.

Hasil dari penelitian ini mendukung penelitian sebelumnya yang dilakukan oleh Gilbert Ayub Tumbel, Jantje Tinangon dan Stanley Kho Walandouw (2017) menyatakan bahwa laba akuntansi berpengaruh signifikan tehadap return saham, Dari hasil penelitiannnya disimpulkan bahwa laba akuntansi berpengaruh positif dan signifikan terhadap return saham karena laba atau keuntungan yang diperoleh dari kegiatan operasional perusahaan akan dibagikan kepada pemegang saham sebagai balas jasa telah menanamkan modalnya dalam perusahaan atau yang biasa disebut dengan dividen. Nantinya dividen tersebut merupakan salah satu komponen penyusun return saham selain capital gain. Perusahaan yang menghasilkan laba semakin besar, maka secara teoritis perusahaan itu akan mampu membagikan deviden yang semakin besar. Dengan meningkatnya dividen yang diterima oleh pemegang saham maka return yang diterima oleh pemegang saham juga akan 
meningkat. Kondisi laba akuntansi yang membaik berdampak nyata pada kinerja saham.

Namun hasil penelitian ini tidak konsisten dengan penelitan yang dilakukan oleh Ilana Thain Spin pada tahun (2020) yang berjudul Pengaruh Arus Kas, Laba Akuntansi, Profitabilitas, Inflasi Terhadap Return Saham Pada Perusahaan Sektor Makanan Dan Minuman Yang Terdaftar Di BEI Tahun 2015-2019" Hasil penelitiannya menunjukkan bahwa laba akuntansi tidak berpengaruh signifikan terhadap return saham. Perbedaan hasil ini dimungkinkan karena penggunaan sampel perusahaan yang berbeda.

\section{Pengaruh Arus Kas Operasi Terhadap Return Saham}

Berdasarkan hasil olah data statistik diketahu bahwa nilai t hitung sebesar $1,629<1,97453$. dan nilai signifikansi 0,105 . Hal ini menunjukkan bahwa variabel arus kas operasi tidak berpengaruh signifikan terhadap return saham. Hasil penelitian ini konsisten dengan penelitian Sri Purwanti, Endang Masitoh W., dan Yuli Chomsatu ( 2015 ), yang menunjukkan bahwa arus kas operasi tidak berpengaruh signifikan terhadap return saham.

Laba dan arus kas merupakan bagian dari laporan keuangan yang dibutuhkan investor sebagai acuan dalam mengambil keputusan investasi. Akan tetapi hasil penelitian ini menunjukkan bahwa arus kas operasi tidak berpengaruh signifikan terhadap return saham. Hal ini dimungkinkan karena investor tidak melihat dan tidak menggunakan informasi arus kas operasi sebagai bahan pertimbangan dalam pengambilan

Keputusan investasi karena kadang kala informasi laba akuntansi dan arus kas operasi menunjukkan informasi yang bertentangan, yaitu kenaikan laba dapat diikuti dengan penurunan arus kas operasi. Sehingga investor lebih memilih untuk menggunakan informasi laba akuntansi dibandingkan arus kas operasi.

Hasil penelitian ini tidak sejalan dengan penelitian yang dilakukan oleh Gilbert Ayub Tumbel, Jantje Tinangon dan Stanley Kho Walandouw (2017) yang menunjukkan hasil bahwa arus kas operasi berpengaruh terhadap return saham. Secara teori, semakin tinggi arus kas operasi perusaha an maka semakin tinggi kepercayaan investor terhadap perusahaan karena perusahaan dianggap mampu menghasilkan arus kas masuk yang baik untuk kegiatan operasionalnya. Hal ini pada akhirnya akan meningkatkan return sahamnya.

\section{Pengaruh Current Ratio Terhadap Return Saham}

Berdasarkan hasil olah data statistik diketahu bahwa nilai t hitung sebesar $0,142<1,97453$. dan nilai signifikansi 0,888 . Hal ini menunjukkan bahwa variabel Current Ratio (CR) tidak berpengaruh signifikan terhadap return saham. Hasil penelitian ini konsisten dengan penelitian Ihsan S. Basalama,Sri Murni,Jacky S.B. Sumarauw ( 2017 ) yang menunjukkan bahwa Current Ratio (CR) tidak berpengaruh signifikan terhadap return saham. 
Current Ratio (CR) merupakan rasio untuk mengukur kemampuan perusahaan dalam membayar kewajiban jangka pendek atau utang yang segera jatuh tempo pada saat ditagih secara keseluruhan. Atau dengan kata lain seberapa banyak aktiva lancar yang tersedia untuk menutupi kewajiban jangka pendek yang segera jatuh tempo. Apabila nilai Current Ratio (CR) rendah, dapat dikatakan bahwa per usahaan kurang modal untuk membayar utang. Kalau Current Ratio (CR) tinggi, dikatakan kondisi perusahaan perusahaan sedang membaik.

Dari hasil uji statistik apabila nilai Current Ratio (CR) yang tinggi maka Return Saham (RS) menjadi rendah. Hal ini dikarenakan nilai Current Ratio (CR) yang tinggi, menunjukkan jumlah kas yang besar. Jumlah kas yang tinggi bisa terjadi karena perusahaan tidak memanfaatkan kas dengan sebaik mungkin untuk mengembangkan usahanya. Karena tidak ada pengembangan usaha, pendapatan perusahaan tidak meningkat dan kondisi perusahaan menjadi stagnan bahkan mengalami penurunan. Karena perusahaan mengalami penururnan, sedikit orang yang ingin berinvestasi pada perusahaan tersebut, dan berdampak pada penurunan harga saham. Jadi pada perusahaan manufaktur periode 2018-2020, menunjukkan bahwa meskipun nilai Current Ratio (CR) tinggi bisa menyebabkan nilai Return Saham (RS) menjadi rendah meskipun nilai pengaruhnya tidak signifikan.

Namun hasil penelitian ini tidak konsisten dengan penelitan yang dilakukan oleh Choirurodin. 2017 yang berjudul "Pengaruh Current Ratio, Return On Equity, Debt To Equity Ratio Terhadap Return Saham (Pada Perusahaan Food and Berverage yang Terdaftar di BEI Periode 2013-2016)". Hasil Penelitian ini menunjukkan bahwa Current Ratio berpengaruh negatif signifikan terhadap Return Saham. Perbedaan hasil ini dimungkinkan karena penggunaan sampel perusahaan yang berbeda.

\section{KESIMPULAN DAN SARAN}

\section{Kesimpulan}

Penelitian ini bertujuan untuk meneliti pengaruh antara Pengaruh Laba Akuntansi, Arus Kas Operasi, dan Current Ratio Terhadap Return Saham Pada Perusahaan Manufaktur Yang Terdaftar di Bursa Efek Indonesia. Berdasarkan hasil penelitian dan pembahasan, maka dapat diambil kesimpulan sebagai berikut:

1. Hasil pengujian hipotesis pertama, variabel laba akuntansi berpengaruh signifikan terhadap return saham (Ha1), diperoleh nilai signifikansi 0,001 dan t hitung yang diperoleh adalah 3,317, Maka nilai signifikansi $0,001<0,05$ dan nilai t hitung 3,317> 1,97453. Sehingga Ha diterima dan Ho ditolak.

2. Hasil pengujian hipotesis kedua, variabel arus kas operasi tidak berpengaruh secara signifikan terhadap return saham (Ho2), diperoleh nilai signifikansi 0,105 dan thitung yang diperoleh adalah 1,629. Maka nilai signifikansi 0,105 $>0,05$ dan nilai thitung 1,629<1,97453. Sehingga Ho diterima dan Ha ditolak.

3. Hasil pengujian hipotesis tiga, variabel current ratio tidak berpengaruh secara signifikan terhadap return saham (Ho3), diperoleh nilai signifikansi 0,888 dan t hitung yang diperoleh adalah 0,142. Maka nilai signifikansi 0,888>0,05 dan nilai t hitung $0,142<1,97453$. sehingga Ho diterima dan Ha ditolak. 


\section{Saran}

Saran-saran yang dapat penulis kemukakan dalam penelitian ini adalah sebagai berikut:

1. Sebaiknya investor memperhatikan variabel laba akuntansi dalam melakukan investasi saham pada suatu perusahaan, karena semakin besar laba akuntansi berarti semakin tinggi pula return saham perusahaan tersebut, sedangkan arus kas operasi dan current ratio merupakan faktor penting dalam menilai kondisi suatu perusahaan sehingga arus kas operasi dan current ratio juga dapat dijadikan pertimbangan investor dalam berinvestasi, walaupun dalam penelitian ini tidak terdapat pengaruh yang signifikan arus kas operasi terhadap return saham.

2. Dalam memprediksi return saham, investor perlu memperhatikan faktor lain yang berpengaruh terhadap return saham, misalnya rasio-rasio keungan lainnya, maupun kondisi ekonomi, sosial, politik dan keamanan.

3. Dalam penelitian lanjutan dengan tema yang sejenis, diharapkan adanya penambahan periode pengamatan dan menambah variabel lain yang belum diteliti, misalnya DPR, DPS dan lainnya.

\section{DAFTAR PUSTAKA}

Agus Harjito dan Martono. 2012. Manajemen Keuangan. Edisi ke-2. Ekonisia, Yogyakarta.

Ang, Robert. 2010. Buku Pintar Pasar Modal Indonesia. Jakarta: Media Soft Indonesia.

Basalama, Ihsan S. Sri Murni. Jacky S.B. Sumarauw. 2017. Pengaruh Current Ratio, DER DAN ROA Terhadap Return Saham Pada Perusahaan Automotif dan Komponen Periode 2013-2015. Jurnal EMBA . Vol.5 No.2 ISSN 23031174.

Choirurodin. 2017. Pengruh Current Ratio, Return on Equity, Debt to Equity Ratio Terhadap Return Saham Pada Perusahaan Food and Beverages Periode 20132016. Prodi Akuntansi Universitas Negeri Yogyakarta

Dwi, Prastowo. 2011. Analisis laporan keuangan konsep dan aplikasi. Edisi ketiga Yogyakarta : sekolah tinggi ilmu manajemen YKPN.

Eduardus, Tandelilin. 2001. "Analisis Investasi dan Manajemen Risiko". Edisi Pertama. Yogyakarta:BPFE.

Ghozali, Imam. 2018. Aplikasi Analisis Multivariate Dengan Program IBM SPSS 25 Cetakan ke-9. Semarang: Badan Penerbit Universitas Diponegoro.

Hanafi, Mahmud. 2010. Manajemen Keuangan. Cetakan ke lima. BPFE.

Yogyakarta

Jurnal Ilmiah Akuntansi dan Ekonomi Volume. 6 Nomor. 2, Agustus 2021 Hal. 16 
Harahap, Sofyan Safri. 2011. Teori Akuntansi. Edisi Revisi 2011. Rajawali Pers. Jakar Jakarta

Hery. 2015. Analisis Laporan Keuangan Pendekatan Rasio Keuangan. CAPS.

Yogyakarta

Ikatan Akuntan Indonesia. 2014. Pernyataan Standar Akuntansi Keuangan. Jakarta : Divisi Penerbitan IAI.

Jogiyanto. 2015. Analisis dan Desain Sistem Informasi.Yogyakarta: Andi Offset

Kasmir. 2014. Bank dan Lembaga Keuangan Lainnya. Cetakan ke-17. Jakarta : Rajawali Pers.

Kasmir. 2018. Analisis Laporan Keuangan. Cetakan Kesebelas. Jakarta.PT: Rajagrafindo Persada.

Muhammad, Zaki. 2017. "Analisis Pengaruh Arus Kas dan Pertumbuhan Laba Jakar Terhadap Return Saham Pada Perusahaan Manufaktur Sektor Industri Dasar Jakar dan Kimia Yang Terdaftar di BEI Tahun 2011-2014”. Universitas Lampung. Jakar Lampung.

Nor Hadi. 2013. Pasar Modal : Acuan Teoretis dan Praktis Investasi di Instrument Keuangan Pasar Modal, Yogyakarta: Graha Ilmu,

Nurmasari, Ifa. 2017." Analisis Current Ratio, Return On Equity, Debt to Equity Ratio, dan Pertumbuhan Pendapatan Berpengaruh Terhadap Return Saham Pada Perusahaan Pertambangan di Bursa Efek Indonesi 2010-2014”. No.1, ISSN : 2339 - 0689, E-ISSN : 2406-8616. Vol. 5,@Prodi Manajemen Fakultas Ekonomi Universitas Pamulang

Nuryaman \& Veronika Christina. 2015. Metodologi Penelitian Akuntansi. Ghalia Indonesia. Bogor

Pramesti, Getut. 2017. Statistika Penelitian Dengan SPSS 24. Kompas Gramedia. Jakar Jakarta

Putra, Yogie Rahmanda. Mimin Widaningsih. 2016. Pengaruh Laba Akuntansi, Komponen Arus Kas, dan Dividend Yield Terhadap Return Saham (Studi pada Perusahaan Sektor Pertambangan di .JurnalRiset Akuntansi dan Keuangan Vol.4 , No.2 . ISSN:2541-061X (Online). ISSN:2338-1507(Print)

Purwanti, Sri. Endang Masitoh W. Yuli Chomsatu. 2015. Pengaruh Laba Akuntansi dan Arus Kas Terhadap Return Saham Perusahaan Yang Listing di BEI. Jurnal Akuntansi dan Pajak vol. 16 no. 01. ISSN : 1412-629X

Rokhanah, Wasis. 2018. Analisis Pengaruh Laba Akuntansi dan Arus Kas Operasi Terhadap Return. Penelitian Akuntansi Saham ( Studi Pada Perusahaan Manufaktur Sektor Aneka Industri Yang Terdaftar Di Bursa Efek Indonesia Periode 2013-2017)". 
Sugiyono. 2017. Metode Penelitian Bisnis. Bandung: Alfabeta.

Sunariyah. 2011. Pengantar Pengetahuan Pasar Modal. Yogyakarta: UPP STIM YKPN.

Syaifuddin.2015. Proposal Penelitian. http://syaifuddin03.blogspot.co.id. 21 september $2020(18 ; 44)$

Spin, Ilana Thain. 2020 yang berjudul Pengaruh Arus Kas, Laba Akuntansi, Profitabilitas, Inflasi Terhadap Return Saham Pada Perusahaan Sektor Makanan Dan Minuman Yang Terdaftar Di BEI Tahun 2015-2019”

Tumbel, Gilbert Ayub, Jantje Tinangon dan Stanley Kho Walandouw.2017. J Jakar "Pengaruh Laba Akuntansi dan Arus Kas Operasi Terhadap Return Saham Jaka Pada Perusahaan Manufaktur Sektor Industri Barang Konsumsi Yang Jakar Terdaftar Di Bursa Efek Indonesia )" Universitas Sam Ratulangi Manado. Jakar Manado.

Yocelyn, Azilia. Yulius Jogi Christiawan. 2012. Analisis Pengaruh Perubahan Arus Kas dan Laba Akuntansi Terhadap Return Saham pada Perusahaan Berkapitalisasi Besar. Jurnal Akuntansi dan Keuangan, vol. 14, no. 2

https://www.kompasiana.com/febrivalentina/5e81ff0bd541df19e644f962/kondisipasar-modal-saat-ini

https://ojk.go.id/id/kanal/pasar-modal/data-dan-statistik/statistik-pasar modal /Documents/4. Statistik Agustus Mgg ke-4 2020.pdf

https://www.pelajaran.co.id/2017/13/pengertian-peran-manfaat-fungsi-jenis-daninstrumen-pasar-modal.html

https://sahammilenial.com/satuan-saham/

http://m.liputan6.com/bisnis/read/4170157/industri-manufaktur-naik-401-persendi-2019

https://www.idx.co.id/perusahaan-tercatat/laporan-keuangan-dan-tahunan/ Diakses Pada 12 desember 2020

https://www.idx.co.id/perusahaan-tercatat/profil-perusahaan-tercatat/ Diakses pada januari 2021

https://www.idnfinancials.com/ Diakses pada 12 desember 2020 